\title{
Research on the Transformation and Upgrading of China's Automobile Industry From the Perspective of Global Value Chain
}

\author{
Yu-Ni TANG* \\ School of Ecnomomics and Management, University of Beijing Jiaotong University, No.3, \\ Shangyuan Village, Haidian District, Beijing, China. \\ Email: tangyuni@bjtu.edu.cn
}

Keywords: GVC, automobile industry, industrial upgrade

Abstract. The automotive industry is an important pillar of a country. It plays an important part in China's economy with its relatively abundant capital and technology, high degree of industrial correlation, and economies of scale. Recent research shows that the automotive industry contributes more than one third of China's GDP. China has now become the world's largest country in the production and consumption of automobiles. However, in the global value chains (GVCs) of the automotive industry, China is in the low-end segment, compared to the high-profit segment of the entire value chain is currently obtained by multinational corporations. This article takes the Chinese automotive industry as the research object, from the perspective of the GVCs theories and four methods of industrial upgrading, to study the path of the transformation and upgrading of China's automotive industry, and to bring about the countermeasures and suggestions.

\section{Introduction}

Since 1990, automotive parts and vehicle manufacturers began to expand globally. For developing countries, export-oriented and import-substitute traditional production model has gradually been replaced by global production. Multinational automotive manufacturers have dispersed their production processes to multiple regions around the world. They integrated local automobile industry and played a leading part in the world's automotive value chain. With the acceleration of the globalization of the automotive industry, multinational companies have placed their main business in higher value-added segment of the industrial value chain, such as automotive sales and after-sales service. At the same time, lower value-added segments have been transferred to developing country. China's auto industry is currently in the low value-added part of the value chain. If China wants to transfer to higher value segments such as research and development and marketing to improve its competitiveness in the global market, it is necessary to improve the production system and promote the further transformation and upgrading of China's auto industry.

Porter (1998) proposed the value chain theory when analyzing the competitive advantages and behaviors of enterprises. In order to apply this theory to a wider range of economic production, based on this theory, scholars have proposed a new global commodity chain. Gereffi (1999) divided the value chain into two driving value chains from the perspective of driving force, which are buyers and producers. The former emphasizes the important role of buyers in global production, and the latter refers to vertical integration of global production by multinational companies. In 2000, scholars in this field replaced the term global commodity chain with Global Value Chains (GVCs) and defined the global value chain as all range of value-creating activities in the entire life cycle from concept design to scrap.

In recent years, many scholars have analyzed the importance of the transformation and upgrading of China's auto industry due to the development of GVCs. Zhao (2009) claims that the upgrading of the automobile industry requires China to choose countries or regions with similar or lagging levels of economic development to invest in order to increase China's market share and competitiveness in these regions. Wu (2010) claims that companies and industries should focus on high value-added segments, starting from strategic layout, design, research and development areas, and gradually enter into the high value-added segment with high "entry barriers". 
Although existing research analyses the current status of China's auto industry from the perspective of GVCs, no specific countermeasures have been given. Based on the theories of global value chains and the theories of industrial upgrading, this article analyses the current status of China's auto industry and also gives corresponding countermeasures.

\section{Overview of Distribution of Global Value Chain in the Automotive Industry}

The GVC of the automotive industry is composed of basic segments such as automotive research and development, component production, vehicle assembly and production, marketing, and automotive services. As shown in Figure 1, its distribution includes two aspects. The first is the value distribution of the value chain. It mainly contains five parts, including automotive research and development, parts production, vehicle production and assembly, marketing, and automotive services. Among them, automotive research and development, key component production, marketing, and automotive services have higher added value, while general parts production and vehicle production and assembly have lower added value. The second is the global distribution of different segments in the automotive industry value chain. Developed countries such as Europe and the United States, Japan and other countries are at the upstream of the global value chain of the entire automotive industry. Their large multinational automotive companies control R\&D and design resources and advanced core production technologies, occupying high value-added services provided by their own automotive brands. While the downstream of the value chain, the majority of developing countries are in the middle reaches, mainly engaged in low value-added links such as general parts production and vehicle production and assembly. The future competition of the automotive industry on the global value chain will mainly focus on higher value-added segments such as automotive research and development, key component production, marketing and automotive services.

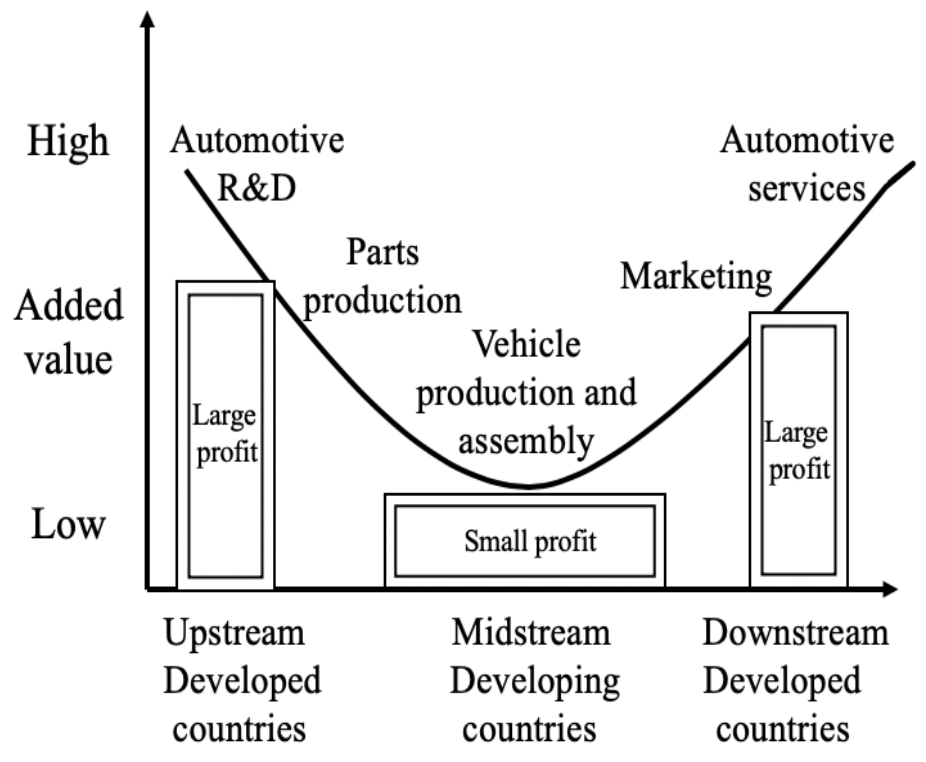

Fig 1. The value and distribution map of the GVC of the automotive industry.

\section{Overview of China's Automotive Industry Development and the Main Issues}

\subsection{China's automotive industry development}

In 2018, China's auto output was 27.809 million, and car sales were 28.081 million, ranking the first around the world for ten consecutive years. China's automobile industry is mainly concentrated in six regions, which are Yangtze River Delta, Pearl River Delta, Northeast China, Bohai Rim, Central China and Southwest China. The Yangtze River Delta area is centered on Shanghai, Jiangsu and Zhejiang. It has the largest car production base and the most complete and largest car parts base in the country. The multinational companies are strong with a good industrial foundation. The Pearl River 
Delta area is centered on Guangzhou and Shenzhen which formed a good development cycle of the automotive industry containing parts research and development, vehicle production, logistics and trade and human resources. The Northeast China, where the automotive industry has a long history, possesses the core auto companies. The Bohai Rim region is centered on Beijing and Tianjin, which not only has convenient transportation but also has advantages on good resources, having great potential in developing automotive industry. The central region is centered on Hubei and Anhui, having obvious advantages in automotive industry with many colleges and universities in this area. Chongqing, as the center in the southwest, the local automotive industry has become an important pillar industry.

\subsection{The main issues}

Nowadays, China's automotive industry has basically formed a multi-variety, full-series production and supporting system for various types of complete vehicles and parts production. China now has become the world's largest automotive production and consumption country. However, as the largest automotive manufacturing country, there are no globally competitive automotive groups and component suppliers. The problems are various, such as relatively low industrial concentration, severely insufficient R\&D investment, weaker influence of independent brands, and insufficient policy support.

The industrial concentration is relatively low. The automotive industry is a typical large-scale industry. Looking at the world's automobile powers, the industrial scale is highly concentrated. In 2011, the world's top eight auto companies including GM, Volkswagen, Toyota, Ford, Renault Nissan, Hyundai Kia, Peugeot Citroen, and Honda sold 51.416 million vehicles, accounting for $67.8 \%$ of global auto sales. In China, more than 17 provinces and 21 cities have the automobile industry as a pillar industry. There are more than 100 automobile manufacturing companies, but only a few companies have annual sales of more than 2 million vehicles, and more than $80 \%$ of the companies have annual sales lower than 200,000 vehicles.

R\&D investment is severely insufficient. Currently, although China's auto companies have realized the importance of independent innovation, the proportion of $R \& D$ investment in sales revenue is much lower than that of large international auto companies. According to relevant data, China 's auto R\&D expenditure accounts for about $1 \%$ of sales, while foreign companies generally reach 3\% -5\%. General Motors of the United States spends 5-6 billion dollars on new product development each year. While in China, the industry's total annual development expenditure is only 2 billion yuan. There is a large gap in both the proportion of $R \& D$ investment and the total investment.

The influence of local brands is relatively weak. Most of China's auto companies have a weak brand awareness and have a large dependence on foreign technology. As shown in the brand value ranking published by Millward Brown, a world-renowned market consulting company, in 2014, the top ten brands in the global automotive industry were mostly American, Japanese, and German companies. Japan's Toyota Motor Corporation ranked first place with a brand value of 29.6 billion dollars in the automotive industry. As the world's largest automotive production and sales country, there is no automotive company has entered into the top ten rankings of automobile brand value.

Policy guidance support needs to be strengthened. For a long time, China's automotive industry has adopted a "market-for-technology" approach, which has greatly promoted the acquisition of foreign advanced technology and management experience. With the rapid development of China's automotive industry, the adjustment of its industrial policy has lagged significantly. Although China has made many adjustments to the policy of the automotive industry, there are still no effective policies or support in independent innovation, major common technologies, independent automobile brands and industry-university-research alliances, etc. 


\section{Development Path of China's Automotive Industry Transformation and Upgrading}

According to the existing theory of industrial upgrading, industrial upgrading refers to the improvement of industrial structure and the enhancement of industrial quality and efficiency. It usually follows a gradual process such as process upgrade, product upgrade, function upgrade, and value chain upgrade, which means an industry will climb from low-value-added state to a high-tech level and a high-value-added state, as shown in Table 1.

Table 1. Industrial upgrading model under the GVC analysis framework.

\begin{tabular}{lll}
\hline $\begin{array}{c}\text { Industrial upgrade } \\
\text { type }\end{array}$ & \multicolumn{1}{c}{$\begin{array}{c}\text { Industrial upgrade } \\
\text { practice }\end{array}$} & \multicolumn{1}{c}{ Performance of industrial upgrade } \\
\cline { 2 - 3 } Process upgrade & $\begin{array}{l}\text { More efficient production } \\
\text { process. }\end{array}$ & $\begin{array}{l}\text { Reduce costs and improve product } \\
\text { development. } \\
\text { Product upgrade }\end{array}$ \\
New product development. & $\begin{array}{l}\text { Increase the market share of new } \\
\text { products and new brands. }\end{array}$ \\
Function upgrade & $\begin{array}{l}\text { Capture higher value-added } \\
\text { segments in the value chain. }\end{array}$ & $\begin{array}{l}\text { Undertake key functions in the value } \\
\text { chain for higher profit margins. }\end{array}$ \\
Value chain & $\begin{array}{l}\text { Stripping of original production } \\
\text { and enter into a new industrial } \\
\text { value chain. }\end{array}$ & $\begin{array}{l}\text { New products become differentiated } \\
\text { products, market share rises, and higher } \\
\text { profit margins are achieved. }\end{array}$
\end{tabular}

The industrial upgrading and development include three levels, which are micro enterprise development level, meso cluster upgrading and development level and macro policy upgrade and development level. The enterprise is the micro-level of the industry, and its market perception, knowledge innovation and social network capabilities are the key factors affecting industrial upgrading and development. The clusters are the meso level of the industry upgrading. The policy is the macro level of the industry upgrading, and its impact on resource integration, industrial structure optimization, market management and technological innovation is related to industrial upgrading and development. Based on the global value chain, this paper constructs the upgrade and development path of China's automotive industry under the global value chain from three levels: enterprises, clusters, and policies, as shown in Figure 2.

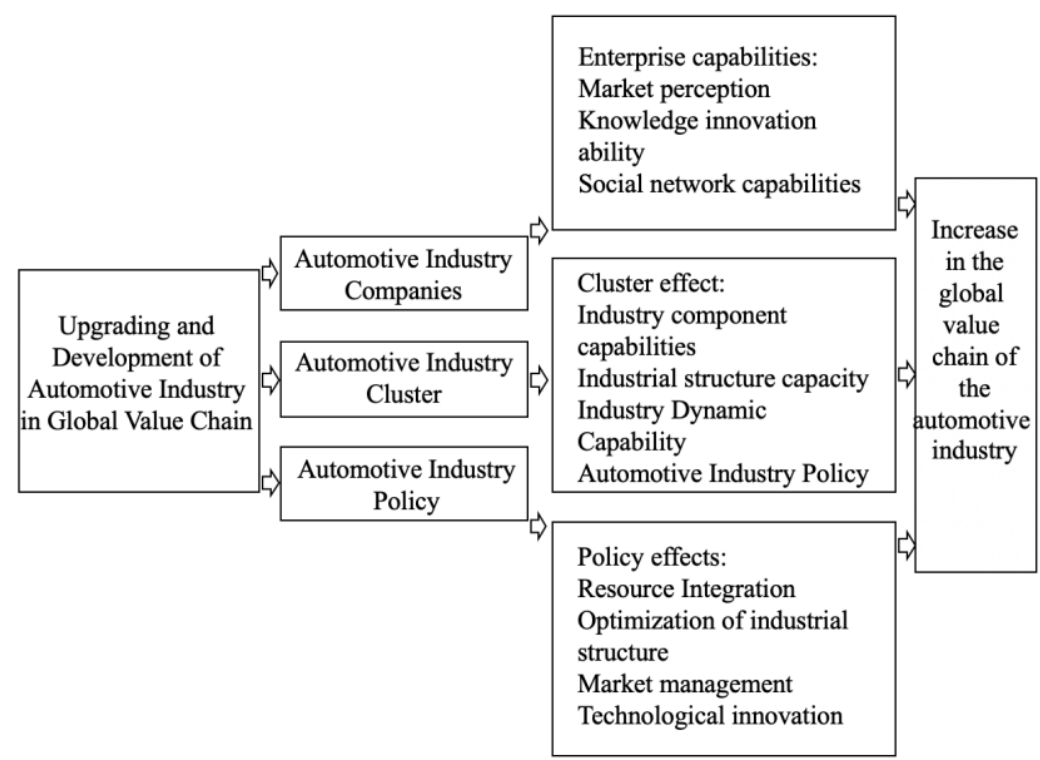

Fig 2. China's automotive industry upgrade and development path under the global value chain. 


\section{Suggestions on the Transformation and Upgrading of China's Automotive Industry}

\subsection{Formulate a strategic plan for the global development of the automotive industry}

The government could formulate a strategic plan for the global development of the automotive industry in China, such as strengthening the investment guidance of the automotive industry, encouraging enterprises to establish overseas $R \& D$ institutions to enhance the strength of innovative technology research and development, as well as regulating the automobile exports order. Also, government could unify the industry with normative guidance for the global development of the automotive industry, making every link of industrial development consistent with the overall interests of China's automotive industry. Thus, the bad image of low-quality and low-cost Chinese automotive brands in the international market could be changed and then establishing a brand-new "China Auto" brand image to improve the international competitiveness of China's automotive industry.

\subsection{Increase support for independent brands}

Currently, China's auto industry's independent brand construction is in the critical time. To give more support, there are several suggestions. Firstly, give preferential tax treatment. The auto industry's own brands implement lower fuel taxes and other taxes, and the self-owned brands exporting abroad implement preferential export tax rebates to enhance their market competitiveness. Secondly, give financial support. In applying for loans from independent brand enterprises in the automobile industry, the approval process should be reduced as much as possible, and the efficiency of lending should be increased to protect the needs of enterprise development funds. Thirdly, give land support. For the auto industry's independent brand enterprises to apply for expansion, the government should give preferential treatment to land use and grant preferential rent to the land they apply for.

\subsection{Accelerate the upgrade and development of China's automotive service industry}

To accelerate the upgrade and development of China's automobile service industry, there are several suggestions. Firstly, strengthen standardized management. Increase the level of management and establish a long-term mechanism for standardized management of the automotive service industry in China. Secondly, improve the qualifications and management system for employees. Require employees in the automotive service industry to have corresponding qualifications and strengthen the qualification review and regular assessment of employees. Thirdly, establish service brand awareness. Adhere to the "customer first" service concept, establish a "service is brand, brand is service" concept, use brand awareness and reputation to enhance service value.

\section{Conclusion}

Multinational companies in developed countries integrate and utilize various global resources, continuously improve the industry's technical standards and industry barriers, and firmly control the high end of the value chain. In China's highly globalized industries, although a large number of international companies have emerged, most of them are still in the low end of the GVC and the lack of independent innovation capabilities are one of the "shortcomings" that restrict the upgrading of Chinese enterprises to excellent multinational companies. Therefore, Chinese enterprises should use GVC resources to continuously explore innovation factors and conduct comprehensive and systematic research International rules and standards for global value chain governance. Through the integration of global innovation resources, cultivate and strengthen the independent innovation elements of Chinese enterprises. From the perspective of the government's macro strategy, we should focus on the following aspects such as improving the national independent innovation strategy, guiding policy, and supporting leading enterprises. Formulate technical standards and implement intellectual property strategies and build a national innovation system to the government, enterprises, research institutions, colleges and universities. 


\section{References}

[1] Gereffi, G., "Shifting Governance Structures in Global Commodity Chains, With Special Reference to the Internet," American Behavioral Scientist, vol.44, no.10(2001), pp.1616-1637.

[2] Humphrey, J. and Schmitz, H., "How does insertion in global value chains affect upgrading in industrial clusters," Regional Studies, vol.9, no.9(2002), pp.1017-1027.

[3] Porter. Michael E. 1998. "Clusters and the New Economics of Competition” Harvard Business Review, pp.24-35. 